\title{
La mirada oblicua de mis dioses
}

- Vladimir Baiza*

\section{Marco Polo toma el Yang-Tsé EN UN CUENCO DE ARROZ}

Mi boca es el Yang-Tsé

$y$ en el limo se lían algas y las

sandalias del mandarín

del templo del Abeto.

El sampán boga hacia las Bocas del Dragón

mientras garzas pliegan sus alas al recodo

¿Quién viene a darme soledad y amargos riscos

y se lleva el fango amarillo hasta el salobre mar

de peces voladores eclosionando entre galeones portugueses?

En Venecia un asesino escupirá de mis memorias

y nadie rabeles dará a la felicidad lejos de las barcazas.

Pero soy el Yang-Tsé

y muevo la placidez desde los bosques

en la Umbría del Este, Cielo en el Estanque

de Cipango y las Especierías.

* El Salvador, 1970. Ha publicado poesía en revistas y periódicos de El Salvador y Nicaragua. Los poemas que incluimos pertenecen al libro La hojarasca raída, ganador del II lugar de los Juegos Florales de San Salvador, 2001. 
Alegre está mi corazón de sangre y viento.

Alegre la mirada oblicua de mis dioses.

\section{MONSTRUario}

I

Hija de la sien y el tarro sin leche

bajo el alba,

el condenado del ocio, su

pesadísima piedra, camina y resbala

ah, breve fulgor de la mañana.

II

Por tu blancura y rizos de alegría

van mis cálices enjutos

mi red de aguas más frescas

la luz menos impura y sin calvicie.

\section{III}

Niña, maldícelo tú, las ratas no disputarán su cráneo, palacio de amargura buscó desde los sueños, retirad su cadáver, migraña escarlata, sed, escozor en el alma bajo el bogavante.

\section{IV}

Del bosque de tecas y guácimos de estrellas qué quedaría

sólo el dolor que menoscaba nuestras brisas efímero universo de caminos que amarillan los embalses y despoblados a sus manos breve fulgor ya sin caricias, rostros quemados en el vado de las fieras casa hirsuta en el límite del polvo 
jícara triste que no brilla cereza de los cercos me persigues amargura desde el fondo de las tazas en la perenniazul espuma de las garzas.

\section{$\mathbf{V}$}

De aquellas mañanas mojadas

En el café de la pobreza

que nos queda

solo el odio que apuntó de nuestros cuerpos, sus magnos placeres, designios de la caja de azucenas oh Yeferin del Monte capellán de la desrisa y los puñales.

\section{VI}

Oh Yeferin

lo peor es que todo

lo nuestro es posible

todo lo nuestro fue posible

todo lo nuestro todo lo todo

siempre fue azul de estrellas hacia

el infinito,

mundo púrpura de anhelos,

todo lo todo

¿Será impertinentemente

posible? 